\title{
The Cooperation of Logistics Among European Countries as These Experiences for South East Countries When It Comes to the Establishment of ASEAN Economic Community
}

\author{
Linh Duy Bui \\ Foreign Trade University, Ha Noi City, Vietnam \\ Toan Huynh Luu Duc \\ Banking University of Ho Chi Minh City, Ho Chi Minh City, Vietnam
}

\begin{abstract}
The called paper presents logistics cooperation activities in European countries, which are put in the situation of establishment of ASEAN Economic Community, particularly South East countries. This will be considered as the experience in managing by government officers as well as the board management of logistics. The authors' methodology is almost descriptive, theoretical analyses. In addition, conducting information-related survey and in-depth interviews by experts will be considered in case of necessary. This paper focuses on Logistic Corporation leading to result in some benefits including bringing on effective in transportation, cutting cost, and saving time; improving the transportation connectivity among countries in ASEAN area; facilitating the construction of infrastructure and legal framework, and assisting to develop regional logistic activity. In this research, the authors focus on analyzing in the period before and after 2015, they attempt to investigate the turning point in the installment of ASEAN Economic Community, including 10 countries with the signed print by the prime minister in these nations. For future research, it is suggested that the cooperation is worth taking into consideration as the innovation related to management activities in microscopes (inside business) as well as macro scopes (countries) in logistics sector. Furthermore, lessons from the success of the European market are the basis foundation for the ASEAN Economic Community in setting up a common market in the field of logistics, shortening time to avoid mistakes and making the intended plan more possible to develop regional logistic activity. Logistic cooperation among nations has played an important and critical role in formation and development of country collaboration, creating the efficiency and capacity of trade among nations of region. Consequently, this paper can provide valuable pointers for shaping AEC.
\end{abstract}

Keywords: cooperation of logistics, ASEAN economic community, European countries

Linh Duy Bui, M.Sc., lecturer, Faculty of Economics and International Business, Foreign Trade University, Ha Noi City, Vietnam.

Toan Huynh Luu Duc, lecturer, Faculty of Finance, Banking University of Ho Chi Minh City, Ho Chi Minh City, Vietnam.

Correspondence concerning this article should be addressed to Linh Duy Bui, Faculty of Economics and International Business, Foreign Trade University, 2nd floor, Block B, \#91 Chua Lang Street, Dong Da District, Ha Noi City, Vietnam. 


\section{Introduction}

In a declaration issued in 2003, during a summit held in Indonesia, ASEAN's leaders agreed to establish the ASEAN Economic Community through enhanced economic integration starting with 11 priority sectors and logistics was included as a priority sector for integration. Thus, the establishment of ASEAN Economic Community is the most important logistics cooperation region and the exchange port channel for all AEC member countries. Therefore, strengthening the regional logistics cooperation for boosting the integration of AEC has a great practical significant on the economic development of ASEAN countries.

The objectives of this paper are the illustration and determination of logistics cooperation among EU countries related to the two main dimensions in economic connectivity, named institutional connectivity and physical infrastructure connectivity in the field of logistics sector. The paper points out that, to establish a successful regional logistics system, harmonization and simplification cross-border procedures as well as transport facilitation should be taken into account. Another objective of the study is to investigate the AEC's regional logistics activities. With suitable conditions related to the share of inland transport and the objective of a single market with free movement of goods like Europe, the study shows proof of high potential of cooperation in logistics among ASEAN countries.

In the following sections, the authors first review the general background and overview on logistics and logistics cooperation. The authors then describe the methodology used in this paper. Subsequently, the authors present research results by addressing the issues of situation of cooperation in logistics sector among Europe and ASEAN countries and proposing some suggestions on boosting the integration in logistics sector among ASEAN members based on European experiences, followed by the two last sections that make some discussing and concluding remarks.

\section{Literature Review}

Cooperation in regional logistics among nations has exerted an essential role in establishment of a common market. It allows countries, especially which individually do not have advantages in highly productive transport network and simplified customs procedures, to activate cost cutting, reduce information and processing lead-time, enhance trade efficiency, and minimize errors to the minimum in logistics activities. It can be expected that the more intense the cooperation among countries, the higher resulting consolidation potential in terms of savings and efficiency increase. However, how to apply and develop logistics cooperation into reality in the effective way to enhance regional logistics competitiveness is another issue. Therefore, in this paper, the authors try to emphasize the illustration of success in operation and benefits gained through logistics cooperation among EU countries, then making the cooperation is becoming more relevant in practice, particularly in the establishment of ASEAN economic community.

Although logistics cooperation has been the focus of various research efforts over the last decades. However, research on AEC's logistics cooperation is limited, especially when integration trend among countries in the same region continues to increase and expand. Therefore, more studies are needed. This paper contributed to literature for being the first paper investigating cooperation in logistics in these regions in economic connectivity perspective. The following below is giving the concepts of logistics and logistics cooperation.

Logistics is a key ingredient in integrating trade and business. Traditionally, logistics is understood as a management concept that is implemented and managed at the firm level. For example, Council of Logistics 
Management (1998) defined logistics as a part of the supply chain process that plans, implements, and controls the efficient, effective forward-reverse flow and storage of goods, services, and related information between the point of origin and the point of consumption in order to meet customers' requirements. Nevertheless, logistics encompasses not only the physical movement of goods, but also the facilitation of movement through the processing of documents, coordination among participants, monitoring of activities, and financing of transactions. Thus, at present, governments have recognized the importance of logistics as a macro-level system that encompasses all stakeholders is needed to develop regional and national logistics development policy. According to Asian Development Bank (ADB) (2010), such logistics system should consist of four main factors: (1) Shippers, traders, and consignees; (2) Service providers; (3) Institutional framework; and (4) Infrastructure (Figure 1).

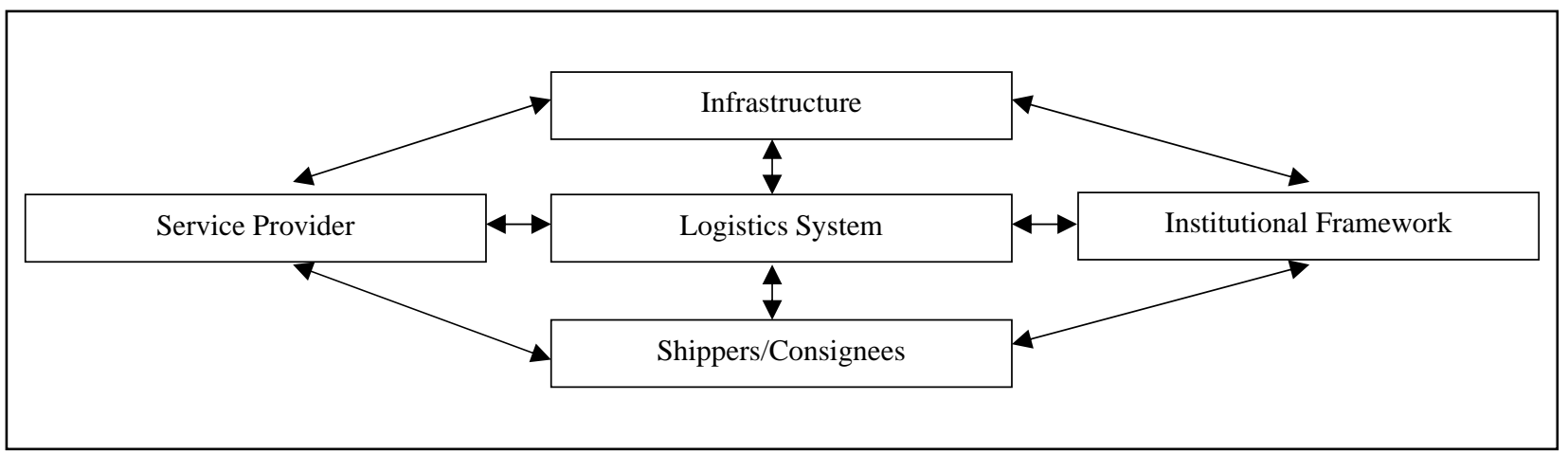

Figure 1. Macro-logistics system dimensions. Source: ADB, 2010.

Shippers, traders and consignees, and service providers are referred as the private sector; on the one hand, infrastructure and the institutional framework are managed by the national governments and regional institutions. On the other hand, regarding economic connectivity, three dimensions are mentioned, institutional connectivity, physical infrastructure connectivity, and people to people connectivity. Since people's connectivity mainly includes tourism, education, and culture, logistics cooperation is more related to institutional connectivity and physical infrastructure connectivity. Therefore, from both perspectives, regarding regional logistics cooperation in this paper, the authors refer to the corporation in the institutional framework and physical infrastructure in particular.

\section{Methodology}

Based on the analysis of importance of logistics cooperation above, it was therefore important for the authors to develop a methodology that could be utilized to help support ASEAN in the formulation of their logistics policy development. The first step of the methodology was based on an understanding of the EU logistics sector. This meant that the status of the sectors related to logistics services needed to be understood in terms of:

- Institutional connectivity including international or regional agreements and protocols related cross-border procedures simplification and transport facilitation;

- Physical connectivity regarding hard infrastructure in transport.

Besides, the authors also gave analysis of the logistics cooperation status among ASEAN countries in the roadmap of formulation ASEAN Economic Community. This analysis enabled the identification of some 
similarities and dissimilarities between EU and AEC that needed to be addressed to give proof for high possibility for enhancing the logistics integration of AEC based on EU policy application.

In the second step of the methodology, the authors gathered information by conducting in-depth interviews by logistics-related experts and authorities in Vietnam including Ministry of Transport and General Department of Vietnam Customs and Vietnam Trade Promotion Agency and other national agencies. In addition, the authors participated in seminars regarding logistics and ASEAN integration. These seminars allowed the authors to do some quick interviews of information collection.

\section{Research Results}

In this section, the authors revealed the characteristics of logistics cooperation between EU and AEC member countries in order to point out similarities and differences between the two regions. It was followed by some policy implications for AEC. The following is an analysis of the information gathered from the research and interviews conducted by the authors.

\section{Situation of Cooperation in Logistics Sector Among EU Countries}

Institutional framework. Institutional connectivity refers to linking various international or regional agreements and protocols to harmonize and simplify cross-border procedures as well as facilitate transport.

First of all, about cross-border procedures, cumbersome trade documentation and procedures can be a problem to intra-community trade as well as trade with the third countries. All members of the EU formed the European Customs Union early in 1990 which imposes unified customs arrangements and allows all goods, whether made in the EU or imported, to circulate freely under Common/Community transit and the International Road Transport Convention. For the goods cross internal borders of member states, no customs formalities are required, which bolsters intra-EU trade (dispatches and arrivals) which represents around 65\% of the total trade of the member states and up to $80 \%$ of the total imports or exports of some countries (Moussis, 2011). Nevertheless, under current rules, territorial waters are considered as the EU's external borders. Therefore, the EU Commission has proposed a Blue Belt package to reduce unnecessary administrative burden for the maritime industry with the introduction of e-Manifest which will allow for proving the EU or non-EU status of goods and ease customs formalities for intra-EU shipping. In addition, to simplify the customs procedures, the EU custom union is constantly working on (i) updating and automating procedures and (ii) the centralization and easier access to simplified procedures. As a part of pan-European e-Government services, in July 2003, they decided to resort to a paperless environment for customs and trade with integrated electronic customs systems for the exchange of data (European Commission, 2014a). Now, a vast majority of customs declarations for both import and export are submitted to customs electronically; the global EU level of electronic input is more than 98\% (European Commission, 2012a). In addition, simplified customs procedures are a key element of EU customs policy. Traders who are authorized to use these procedures benefit from an accelerated customs clearance process such as incomplete declaration, simplified declaration, and local clearance, with the result that they have the goods at their disposal more quickly. According to European Commission (2012b), 78\% of all imports and 71\% of all exports are made using simplified procedures. These simplified procedures are supported by Single Authorization for Simplified Procedures (SASP) or Centralized Clearance and the recognition of Authorized Economic Operator (AEO). SASP enables an economic operator to centralize the accounting and payment of customs duties for all his/her transactions in the member state 
where he/she is established, regardless of the place where the movement of goods occurs. The physical control and release of goods may take place in another member state. Besides, to avoid the adverse impacts of some security measures, AEO status has been introduced to put enterprises in stronger position to benefit from simplified procedures. The AEO status granted by one member state is recognized by the other member states and member states should grant the use of simplifications to AEO if they meet specific requirements and without re-examining criteria that have been already checked.

Furthermore, the transport facilitation is supported by a number of legislations to harmonize the transport policy in EU such as the single multimodal transport documents, Single European Sky, the consistent road user charges, social and safety legislation, and transposition and enforcement of legislation in the member states.

Physical infrastructure. Physical connectivity in logistics cooperation mainly encompasses hard infrastructure in transport.

Well-developed infrastructure reduces the effect of distance between regions, integrates the national market, and connects it to markets in other countries and regions. Overall, the infrastructure of EU state members is well-developed; however, as illustrated with the competitive index 2013-2014, some countries have outstanding quality of infrastructure like Germany, France, Netherlands, and United Kingdom at the top 10 while that of others like Bulgaria, Poland, and Romania is below the world's average level. Therefore, besides the development of individual member; the transport policy of EU these days is designed in favor of more coordination and the harmonization of regulations and physical transport systems. About the disparity among member states, not all countries can be logistics hub for international distribution but thanks to the free circulation of goods within EU, products can leave or enter the continent transit through the "Blue Banana" cities which are strategically located at the economic heart of Europe including Netherlands, Belgium, and Western and Southern Germany down to Switzerland and Northern Italy (Colliers International, 2013). These cities all have developed infrastructure network with Europe's largest freight airports and seaports, which function as gateways towards non-EU markets. Second, in early 1990s, the policy has shifted towards a balance with development of integrated transport systems and the development of transport infrastructure for the purpose of strengthening economic and social cohesion so as to reduce disparities between the regions (Giorgi \& Schmidt, 2002). That later on led to the birth of the trans-European Networks (TEN) in 1996 with Decision No. 1692/96/EC. In addition, a network connecting the continent between East and West, North and South is essential because of some following factors: the tendency of shifting from nationally based manufacturing to pan-European systems (Piecyk \& McKinnon, 2010), the gaps among the transport networks of member states, and the technical barriers such as incompatible standards for railway traffic (European Commission, 2014b). Regarding the financing scheme, although national budgets are still the main source of finance; member states have resorted to other sources of funds like European Investment Bank, Ten-T, cohesion fund, and European Development fund. Among these other sources, cohesion fund accounts for the largest part. Cohesion fund is formed by the contribution of member states; it is also the evidence of benefits caused by integration. A study has found that Germany, one of the European Union's largest fund contributors, is also the top indirect beneficiary from payments to four Central European member states when each euro that Germany pays into EU cohesion funds generates 1.25 euros (1.66 dollars) in revenues from exports to those states (EU Business, 2012). In addition, Ten-T is the next large other source with the PPP (Public Private Partnerships) arrangements based on the procurement of services. Direct funding support for PPPs was made available for the first time in the 2010 Ten-T Annual Call for Proposals. Although PPP is still new with not large contribution to the projects at 
the moment, with large and complex projects, the European Commission committed to "explore the opportunities that can come from a greater involvement of the private sector” (European PPP Expertise Centre, 2003).

\section{Cooperation in Logistics in AEC}

As can be seen in AEC blueprint in 2008, AEC's move to 2015 is quite similar to that of EU. First, about institutional framework, AEC aims to (i) customs integration and (ii) single market in transport sector. The customs integration in AEC is accelerated with simple and harmonized customs procedures and formalities, ASEAN Customs Transit system, ASEAN e-Customs, Mutual Recognition Arrangements, and a uniform system of tariff classification. Particularly, the ASEAN Framework Agreement on Goods in Transit is one of major agreements; it was proposed in 1998 but nine protocols forming integral parts of this agreement have not all finalized, signed, and ratified. Recently, in 2013, an important part, Protocol 7-Customs Transit System was signed by all ASEAN members except Thailand and the Philippines. Nevertheless, this agreement covers the transit of land transport including road and rail transport only. In addition, Single Window will be developed as an environment where 10 National Single Windows of individual member countries operate and integrate. National Single Window enables a single submission of data and information, a single and synchronous processing of data and information and a single decision-making for customs clearance of cargo, which expedites the customs clearance, reduces transaction time and costs, and thus enhances trade efficiency and competitiveness. In addition, ASEAN has introduced a number of transport facilitation initiatives over the years to create an efficient logistics and multimodal transport system to connect land, maritime, and air transport such as ASEAN Framework Agreement on Multimodal Transport, ASEAN Framework Agreement on the Facilitation of Inter-State Transport, Roadmap for Integration of Air Travel Sector, and Roadmap Towards an Integrated and Competitive Maritime Transport in ASEAN. It is notable that the transport facilitation does not only encompass the seamless transport route like the ASEAN Open Sky Policy; but it also can be reflected by the liberalization of the maritime and air transport sector which should lead to competitions and subsequent lower costs and increased quality of services and timeliness.

Second, regarding physical infrastructure development, integrated transport network has been implemented to connect ASEAN members as well as ASEAN with the neighboring Northeast and South Asian countries. Specifically, under AEC blueprint, ASEAN Highways and Singapore-Kunming Rail Link are the priority projects. ASEAN Highways is an expansion of the "Trans-Asian Highway" network within ASEAN; both cover all member states in ASEAN. Singapore-Kunming Rail Link only covers several routes in mainland Southeast Asia through Singapore-Malaysia—Thailand—Cambodia—Viet Nam-China (Kunming) and spurs lines in Thailand-Myanmar and Thailand—Lao PDR. Nevertheless, these projects still cannot bridge the mainland Southeast Asia and the island Southeast Asia; for examples, the Philippines, as an island Southeast Asia country, does not share its border and has no highway or railway linkages with any other ASEAN countries. As regard infrastructure financing, the ASEAN Infrastructure Fund was established as a corporate entity wholly owned by government and the ADB and issue bonds for additional funding; with projected $70 \%$ co-financing by ADB, the Fund plans to leverage more than $\$ 13$ billion in infrastructure financing by 2020 (ADB, 2012).

The logistics cooperation in AEC is the continual and more comprehensive efforts from ASEAN agreements and projects such as the agreement in customs and transport or the ASEAN Highways with a ministerial understanding in 1999 and Singapore-Kunming Rail Link initiated in 2006. AEC seems to be a further step toward a more integrated and interdependent ASEAN when pursuing deeper integration of markets and production 
systems. For example, the implementation of ASEAN Single Window or Mutual Recognition Arrangements or a more an ASEAN single shipping market requires more national adjustment beyond trade liberalization.

\section{Similarities and Dissimilarities Between EU and AEC}

Regarding logistics, AEC and EU are similar in (i) the disparity in development level of member states, (ii) the share of inland transport, and (iii) the objective of a single market with free movement of goods and improvement of the regional competitiveness. These similarities will be the ground for further move of AEC. First, both AEC and EU are handling with the development gap among member states including the difference in infrastructure quality and incompatible standards. Second, although ASEAN's geographical location is more diversified with the sea area of about three times larger than its land counterpart (ASEANFIC, 2014), inland transportation is the main mode in term of shares of intra-ASEAN merchandise trade values (Meyrick, 2005). That was similar to the situation of EU when more than a half of intra-EU goods transport is road in 2010. Third, the AEC and EU both share the spirit of the economic integration with the simplification, harmonization in trade, and customs. In addition, as mentioned above, both AEC and EU have been very active in developing the regional integrated network transportation.

Nevertheless, despite the resemblances mentioned above, AEC and EU are dissimilar in (i) the main driving force of economic integration, (ii) institutional structures, (iii) the external policy, and (iv) geographic diversity and national advantages. First, intra-ASEAN trade is only about one fourth of its global trades while in the case of EU, it is two thirds (Hamada, Resza, \& Volz, 2009). Thus, it is suggested that EU is a large economic space with developed economies with high consumption and production volume. ASEAN and AEC's commitments should be more investment agreements than trade agreements or focus on single production base rather than the single market. It is reasonable when parts and components and final assembled products accounted for 66.1\% of ASEAN exports and 64.0\% of ASEAN imports in 2006-2007 (Asian Development Bank Institute, 2013). Moreover, it is supportive of Asia's new growth model of a regional production hub and increasing intraregional trade, $70 \%$ of intra-East Asian trade comprises trade in parts and components which are then assembled into final goods and exported to other countries, particularly the United States and the EU (ADB, 2007). This pan-ASEAN production base is the most apparent in the electronics and automotive sectors which have long value chains (Asian Development Bank Institute, 2013). Hence, in that manner, AEC is more open globally integrated or more "outward looking” (ASEAN Secretariat, 2008) and free circular of goods will attract more FDI as a vertical integrated market. Second, while EU focuses on the pooling of sovereignty for common gains with supranational policy-making bodies like the European Central Bank or the European Commission, AEC respects of national sovereignties of each member state and makes decision based on consultation and consensus (Chairasmisak, 2012). Besides, the rotation of ASEAN chairmanship every five years may expose ASEAN to the leadership problem; more specifically, that a series of officials from the poorer, less developed ASEAN countries will be the chair of ASEAN for the next few years means that leadership will be inexperienced and possibly be less interested in pushing ahead quickly with integration on all fronts. Third, despite the common policy on intra-community trade, at present, AEC is not a customs union with the different external policy; that implies the possible competition among countries and may disrupt the process for single market. Fourth, the competitive advantages and income level of most ASEAN countries rather resemble each other; except for Singapore and Brunei, others are developing countries which emphasize exports and foreign investment and are likely to compete for inbound investment and jobs (Runckel, 2012). In 
addition, geographically, ASEAN can be divided into mainland and island countries; such geographical diversity of ASEAN countries also makes it hard to foster the connectivity and interdependence among nations. Consequently, in addition to the regional disparity and competition, the lack of leadership and the entity for implementation and enforcement of such economic community may slow the integration process including the logistics cooperation (Runckel, 2012). Additionally, the weaker integration and interdependence and the lower level of development of some member states may also cause the problem in infrastructure financing.

\section{Policy Implications for AEC}

If all countries in the ASEAN were to improve border efficiency and infrastructure to half the level of Singapore, then exports from Southeast Asia would increase by around $12 \%$ and regional GDP would increase by more than 9\% (Bain \& Company and the World Bank, 2013). That shows the necessity of logistics improvement of ASEAN countries. This paper will not focus on the fundamental issue of AEC such as basic principle of decision-making in ASEAN of consultation and consensus or its institutional structure because it seems that "the AEC is not, and has no intention of transforming ASEAN into a European style union" (Trairatvorakul, 2011). Instead, it proposed some measures to enhance the institutional and physical infrastructure in logistics cooperation under the current ASEAN scheme.

\section{Cross border procedure's simplification and harmonization for both intra-ASEAN trade and trade} with the third countries. As for cross border procedure harmonization toward intra-ASEAN trade, it appears that the ASEAN governments have exerted a number of efforts to streamline the procedure for goods transit of intra-ASEAN trade. The objective of single market and production base would be not possible without more harmonized policy toward outside trade even if it means that certain sovereignties may be given up. Since ASEAN is more outward looking with the large share of trade with non-ASEAN countries, these streamlines will increase the competitiveness of the region. In addition, harmonization would not be sufficient for an effective policy. It is recommended that ASEAN should follow the pattern of EU with the application of incomplete declaration, simplified declaration and local clearance, or Single Authorization for simplified procedures or Centralized Clearance or the recognition of Authorized Economic Operator as discussed above.

Promoting the rail and the maritime transport. As illustrated in Figure 2, the intra-ASEAN trade is mostly between ASEAN mainland countries; the trade between ASEAN mainland and ASEAN islands or between ASEAN mainland countries is not significant. It may be due to the missing link between ASEAN islands and ASEAN mainland. Particularly, as for the Philippines; it is an important location in ASEAN single production base with the parts and components export of 71.7\% and import of 61.3\% in 2006-2007 (Asian Development Bank Institute, 2013), but there has no highways or railways link in physical infrastructure projects in ASEAN. Thus, a harmonized and simplified port procedure will better facilitate and foster intra-trade of ASEAN, particularly the trade between ASEAN islands and ASEAN mainland and among ASEAN islands as well as develop single production base in ASEAN. In addition, concerning goods transit agreement, it seems that AEC has not covered the goods movement from one port to another in ASEAN. Therefore, to promote the single market and production base, port facility as well as procedure should be improved; it can follow the Blue Belt package of EU as mentioned above. Since a vast majority of containers have mixed cargo, it will require the application of a system for proving the community or non-community status of goods (e-Manifest in EU); any community goods on board do not need customs supervision in order to speed up of customs procedures for such cargos. 


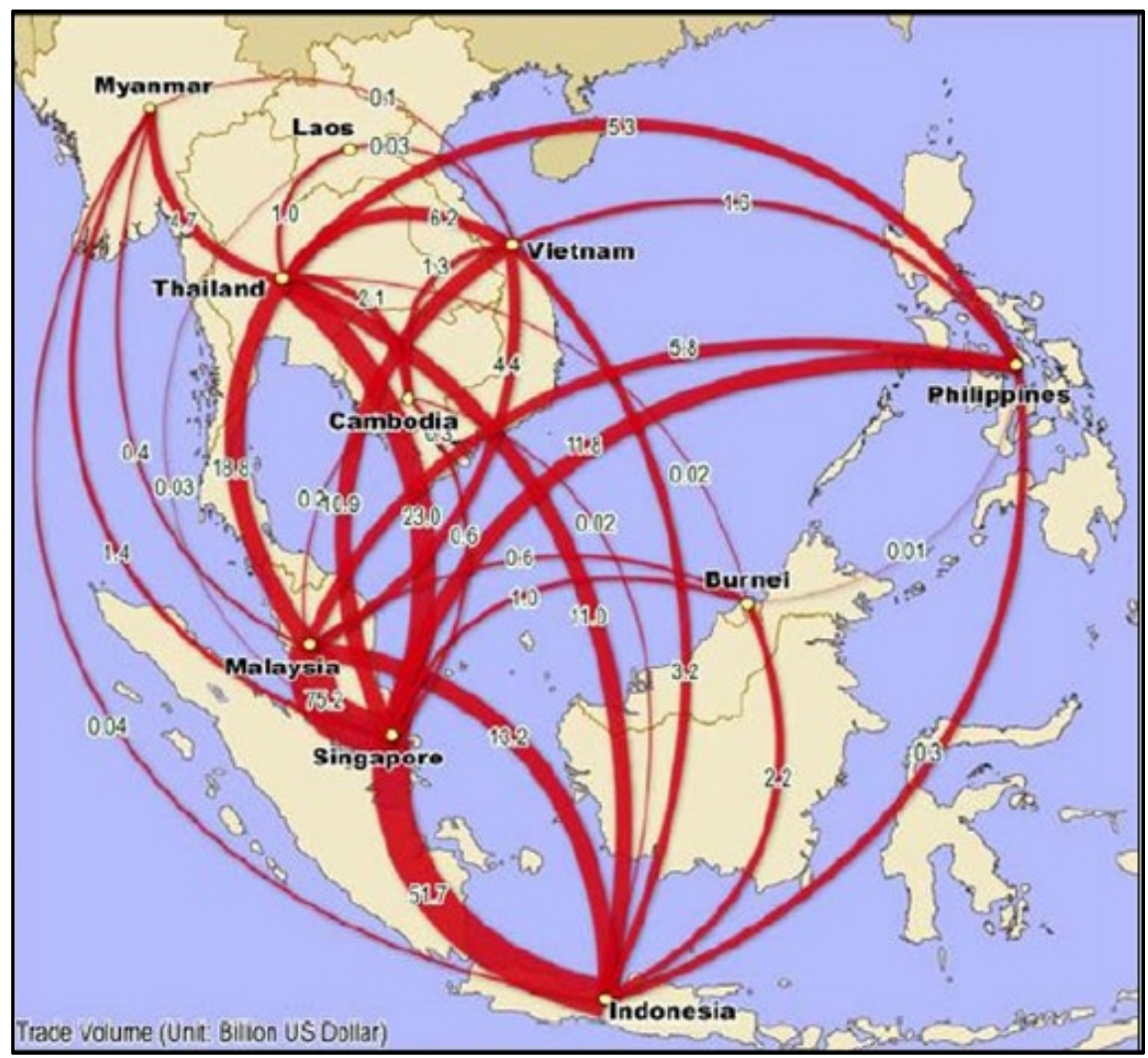

Figure 2. Trade volume among ASEAN member states. Source: ERIA Study Team (2010).

Considering the fact that land transport is the main mode in ASEAN, rail should also be given the adequate priority. Rail transport is less costly in environmental terms than road transport and may offer a competitive alternative to the latter on certain major segments of the market. The recent policy on EU rail freight development has shifted the land transport from road to rail mode; they even raise the road fee to encourage the use of rail freight. The rail and maritime transport not only help ASEAN to fully recognize its potential as a single market and production base; it also reduces the impact of transport on global warming and energy shortage which is the problems that ASEAN, EU, and other economies are now facing.

Table 1

Comparison of Transport Mode

\begin{tabular}{lll}
\hline Transport mode & $\begin{array}{l}\text { Approx. relative energy } \\
\text { consumed per freight ton }\end{array}$ & $\begin{array}{l}\text { Approx. relative carbon }\left(\mathrm{CO}^{2}\right) \\
\text { emission per freight ton }\end{array}$ \\
\hline Ship & 1 & 1 \\
Railway & 3 & 2.5 \\
Truck & 3 & 6 \\
Aircraft & 120 & 60 \\
\hline
\end{tabular}

Source: ERIA Study Team (2010).

Financing infrastructure with cohesion fund and PPP proposal. Cohesion fund in ASEAN has been considered for a long time; but the low level of overall income compared to EU and the reluctance of ASEAN's leaders has deterred the process. ASEAN has large economic powerhouses such as Singapore, Thailand, or Malaysia like EU with Germany and France while Laos and Cambodia are struggling with infrastructure 
finance. The cohesion fund is believed to benefit both the contributors and the receivers like the case of Germany and four Central European member states above said. The need for a cohesion fund is more intense considering the fact that for Laos, the finance source of the Singapore-Kunming railway will be a loan from China nearly which is as big as Laos's formal economy (T. J., 2013). The cohesion fund is one step to a more interdependent ASEAN to bridge the gap among its member states and most importantly, to reduce the dependence on the outside. In addition, for such large infrastructure project, PPP can be considered as a potential option. On one hand, it is additional finance source to national budgets; on the other hand, it reduces the dependent of foreign loan like the case of Laos. Nevertheless, PPPs require more detailed project preparation in order to achieve appropriate risk sharing with the private sector. In the case of ASEAN, it needs joint efforts and programs like the Ten-T annual call for proposal in EU for the sake of the overall region.

\section{Discussion}

Regional logistics cooperation is a difficult topic that attracts the attention of many ASEAN member countries in the roadmap to establish the common logistics market. However, cooperation in logistics within ASEAN is needed under the requirements of integration that becomes stronger nowadays. The authors hope that this paper could provide some practical ways to boost logistics integration among ASEAN countries based on the experience of EU in formulating and adopting its regional logistics policy.

However, the main limitation of the methodology was that the authors were not able to conduct interview from all governments and related authorities of other member countries. The second limitation was that the paper does research based on the economic connectivity perspective related to agreements and protocols to enhance regional logistics and infrastructure for transport. Therefore, for further research, the authors suggest that other perspective of logistics integration should be taken into account.

\section{Conclusion}

The ASEAN logistics sector is characterized by relative high cost, long lead time for import and export procedures, and an uneven level of logistics sector development among member countries. Customs simplification and transport facilitation issues seemed to be improved in order to boost integration in these related logistics sectors among ASEAN countries.

Based on logistics and logistics operation theories, analyzing institutional framework and physical infrastructure of cooperation in logistics among EU countries, three suggestions are given to enhance integration in logistics of ASEAN country members. Conclusions are drawn as follows:

(1) Simplifying and harmonizing cross border procedure for both intra-ASEAN trade and trade with the third countries to increase the regional logistics competitiveness;

(2) Promoting transport especially the rail and the maritime to foster intra-trade of ASEAN and developing production base as well as lessen the adverse impact of transport on global environment;

(3) Giving finance for infrastructure with cohesion fund and PPP proposal to bridge the uneven level gap among ASEAN members and reduce the dependence of foreign loan.

\section{References}

ASEAN Secretariat. (2008). ASEAN Economic Community Blueprint. Association of Southeast Asian Nations. Retrieved from http://www.asean.org/archive/5187-10.pdf at 29th March 2014.3

ASEANFIC. (2014). ASEAN Financial Institution Conference. Kuala Lumpur, 2014. 
Asian Development Bank (ADB). (2007). Asian development outlook 2007 update. Manila: Asian Development Bank.

Asian Development Bank (ADB). (2010). Logistics development and private sector competitiveness. Business Forum for logistics.

Asian Development Bank (ADB). (2012). Facts and data about Southeast Asian infrastructure. Retrieved on 29 March 2014 from http://www.adb.org/features/fast-facts-asean-infrastructure-fund

Asian Development Bank Institute. (2013). The ASEAN economic community: Progress, challenges, and prospects. Tokyo: Asian Development Bank Institute.

Bain \& Company and the World Bank. (2013). Enabling trade valuing growth opportunities. World Economic Forum.

Colliers International. (2013). Top European logistics hubs-European logistics. White Paper for Research.

Council of Logistics Management. (1998). CSCMP Supply Chain Management. Retrieved on 29th March 2014 from http://cscmp.org/about-us/supply-chain-management-definitions

Chairasmisak, S. (2012). The ASEAN Economic Community and the European Union's experience: The purpose, the inception, the difference, and the issue. Retrieved on 29th March 2014 from http://siampremier.com/asean-economic-community-and-the-european-unions-experience/

ERIA Study Team. (2010). “Introduction” in ASEAN Strategic Transport Plan 2011-2015. Jakarta: ASEAN Secretariat and ERIA, pp. 1-12.

EU Business. (2012). Germany top indirect beneficiary of EU cohesion funds: Study. Retrieved on 29th March 2014 from http://www.eubusiness.com/news-eu/poland-budget-czech.fhx

European Commission. (2012a). Customs is business friendly. Retrieved on 29th March 2014 from http://ec.europa.eu/taxation_customs/customs/policy_issues/facts_and_figures/customs_business_friendly_en.htm

European Commission. (2012b). Road transport: A change of gear. Luxembourg: Publications Office of the European Union.

European Commission. (2014a). Legislation related to the electronic customs initiative. Retrieved on 29th March 2014 from http://ec.europa.eu/taxation_customs/customs/policy_issues/electronic_customs_initiative/electronic_customs_legislation/ind ex_en.htm

European Commission. (2014b). Infrastructure-TEN-T-Connecting Europe. Retrieved on 29th March 2014 from http://ec.europa.eu/transport/themes/infrastructure/index_en.htm

European PPP Expertise Centre. (2003). A guide to guidance-Sourcebook for PPPs in Ten-Transport. Luxembourg: European PPP Expertise Centre.

Giorgi, L., \& Schmidt, M. (2002). European transport policy-A historical and forward looking perspective. Policy Studies/Politikfeldanalyse, 2(4), 1-19.

Hamada, K., Resza, B., \& Volz, U. (2009). Towards monetary and financial integration in East Asia. Bonn: German Development Institute.

Moussis, N. (2011). Access to European Union law, economics, policies (19th ed.). Rixensart: European Study Service.

PDP Australia Pty Ltd and Meyrick and Associates. (2005). Promoting Efficient and Competitive Intra-ASEAN Shipping Services. Malaysia Country Report, REPSF Project 04/001, 29.

Piecyk, M. I., \& McKinnon, A. C. (2010). Analysing global energy trends in road freight transport. Supply Chain Perspective, 11(2), 31-42.

Runckel, C. W. (2012). Asia Opportunities: Asean Economic Community (AEC) in 2015. Retrieved on 29th March 2014 from http://www.business-in-asia.com/asia/asean_economic_community.html

T. J. (2013). One night to Bangkok. The Economist. Retrieved from http://www.economist.com/blogs/banyan/2013/09/infrastructure-laos at 29 March 2014

Trairatvorakul, P. (2011). ASEAN economic community 2015: Opportunities or threats? Speech presented at Sasin Update-Reunion 2011, Thailand. 